\title{
INTERAKSI BI-TROFIK KOMUNITAS SERANGGA TANAMAN KEDELAI DENGAN TIGA TEKNIK PENGELOLAAN HAMA DI NGAWI, JAWA TIMUR
}

\section{BI-TROPHIC INTERACTION OF SOYBEAN INSECT COMMUNITY WITH THREE PEST MANAGEMENT TECHNIQUE IN NGAWI, EAST JAVA}

\author{
Ciptadi Achmad Yusup ${ }^{* 1,2}$, I Wayan Winasa ${ }^{3}$, Purnama Hidayat ${ }^{3}$ \\ ${ }^{1}$ Program Studi Entomologi, Sekolah Pascasarjana, Fakultas Pertanian, Institut Pertanian Bogor \\ ${ }^{2}$ Pusat Penelitian Bioteknologi dan Bioindustri Indonesia \\ ${ }^{3}$ Departemen Proteksi Tanaman, Fakutas Pertanian, Institut Pertanian Bogor. Jl. Kamper Kampus IPB \\ Dramaga, Bogor, Indonesia 16680 \\ Korespondensi e-mail: ciptadi.a.yusup@gmail.com
}

(diterima Juni 2019, direvisi Oktober 2019, disetujui Desember 2019)

\begin{abstract}
ABSTRAK
Serangga sebagai bagian dari struktur trofik pada ekosistem kedelai memiliki peran utama sebagai hama, musuh alami, dan juga sebagai dekomposer. Studi ini menekankan serangga sebagai hama kedelai dan sebagai musuh alami hama kedelai. Interaksi antara serangga hama dan musuh alaminya dipengaruhi oleh sistem budidaya tanaman, diantaranya pengendalian hama dengan menggunakan insektisida. Pada penelitian ini, tiga teknik pengelolaan hama, yaitu teknik pengelolaan hama campuran, kimiawi, dan versi petani dibandingkan untuk mempelajari pola interaksi antara serangga hama dan musuh alaminya. Penelitian dilakukan pada bulan Juni hingga September 2014 dengan beberapa metode seperti pengamatan langsung, penggunaan perangkap lubang jebakan dan jaring serangga. Penyusunan pola interaksi bi-trofik berdasarkan hasil pengamatan langsung dianalisis menggunakan software R. Statistic, sedangkan komposisi serangga dianalisis berdasarkan data serangga yang terkoleksi dari lubang perangkap dan jaring serangga. Hasil penelitian menunjukkan bahwa pola interaksi bi-trofik antara serangga hama dan musuh alaminya pada teknik pengelolaan hama kimiawi sedikit lebih renggang dibandingkan dengan dua teknik pengelolaan hama lainnya. Pola interaksi yang terbentuk menunjukkan bahwa kutukebul (Bemisia tabaci) merupakan serangga fitofag yang paling dominan, dan kumbang Menochillus sexmaculatus merupakan musuh alami yang paling dominan ditemukan di lahan kedelai. Teknik pengelolaan hama versi petani memiliki keanekaragaman serangga yang sedikit lebih tinggi dibandingkan dengan dua perlakuan lainnya.
\end{abstract}

Kata kunci: Hama kedelai, insektisida, interaksi trofik, komposisi serangga, musuh alami.

\begin{abstract}
Insect as part of trophic structures in soybean ecosystem play major roles as pest, natural enemy for pests, and decomposer. This study highlighted insect as soybean pest and natural enemy for soybean pest. The interactions between insect pests and their natural enemies are affected by cultivation system, such as pest control by using insecticide. In this experiment, three pest management techniques; mixed, chemical, and farmer's pest management techniques were compared to observe interaction pattern between insect pests and their natural enemies. The research was conducted from June to September 2014 using several methods including direct observation, pitfall trap, and insect net. Bi-trophic interaction patterns based on the results of direct observation were compiled and analyzed using $\mathrm{R}$ statistic software, while diversity and abundance of insects were analyzed based on data of collected insect from pitfall trap and insect net. The result showed that bi-trophic interaction pattern of insect pests and their natural enemies was less dense in the chemical pest management technique. The interaction patterns showed that the whitefly (Bemisia tabaci) was the most dominant phytophagous insect, and the ladybug (Menochilus sexmaculatus) was the most dominant natural enemy found on soybean field. The farmer's pest management technique has slightly higher insect diversity compared to other treatments.
\end{abstract}

Keywords: Insect composition, insecticide, natural enemy, soybean pest, trophic interaction.

\section{PENDAHULUAN}

Jejaring makanan merupakan hubungan antara tingkatan trofik organisme yang saling mengeksploitasi satu sama lain dan terdiri dari minimal tiga tingkatan trofik dan lebih dari dua spesies yang terlibat pada masing-masing tingkatan trofik (Begon et al. 2003). Begon et al. (2003) juga mendeskripsikan kompetisi intraspesies pada masing-masing tingkatan trofik yang berbagi sumberdaya yang sama akan saling menekan demi mempertahankan hidup. Kompetisi ini yang memengaruhi struktur atau pola interaksi yang terbentuk di suatu lingkungan. Struktur trofik tersebut 
dipengaruhi oleh berbagai faktor yang memengaruhi kepadatan populasi masingmasing tingkatan trofik yang terhubung (Loch et al. 2020; McCary et al. 2016). Interaksi bi-trofik melibatkan hubungan antara struktur trofik pada dua tingkatan trofik. Kestabilan jejaring makanan di ekosistem alami sangat dipengaruhi oleh keberadaan dan tingkat populasi dari masing-masing spesies pada masing-masing tingkatan trofik (Allesina et al. 2015; McMeans et al. 2015; Mougi \& Kondoh 2016).

Lahan pertanaman kedelai merupakan suatu habitat lokal yang kompleks dan terdiri atas beberapa struktur trofik. Habitat lokal di lahan atau skala kebun dapat dimanipulasi agar kondisinya sesuai atau biasa disebut manajemen habitat (Gurr et al. 2017; Hassan et al. 2016). Dalam praktik pengendalian hama, aplikasi pestisida merupakan cara yang paling umum digunakan oleh petani kedelai Indonesia. Pestisida merupakan salah satu sarana untuk melakukan manajemen habitat yang digunakan oleh petani, namun aplikasi pestisida yang bertujuan untuk mengurangi kehilangan hasil akan menyebabkan penurunan biodiversitas spesies serangga (Heraty 2017).

Dampak dari praktik pengendalian hama pada komunitas serangga di pertanaman kedelai dapat dilihat melalui pendekatan jejaring makanan (Macfadyen et al. 2015; Malard et al. 2020). Serangga memiliki peranan yang sangat penting dalam berbagai jenis ekosistem (Macfadyen et al. 2015). Serangga merupakan salah satu penyusun tingkatan trofik yang penting pada ekosistem pertanaman kedelai, terutama perannya sebagai hama dan juga sebagai musuh alami yang menekan populasi hama. Pada penelitian ini, interaksi bi-trofik yang mencakup serangga hama kedelai dan musuh alaminya digunakan untuk melihat efek dari teknik pengelolaan hama terhadap komunitas serangga yang ada.

\section{METODE PENELITIAN}

\section{Lokasi dan Waktu Penelitian}

Penelitian ini dilaksanakan di kebun percobaan kedelai milik Balai Penelitian Tanaman Aneka Kacang dan Umbi (BALITKABI) di Ngale, Kabupaten Ngawi, Jawa Timur. Identifikasi serangga yang diperoleh dilaksanakan di Laboratorium Biosistematika Serangga, Departemen Proteksi Tanaman, Fakultas Pertanian, IPB. Identifikasi serangga dilakukan dengan menggunakan kunci identifikasi (Choate 1990; Disney \& Fayle 2008; Dondale \& Redner 1990; Froeschner 1996; Goulet \& Huber 1993; Jocqué \& Alderweireldt 2005; Masner 1980; McAlpine 1987; Rao \& Hayat 1983; Slater \& Baranowski 1990; Smith \& Holmes 2002; Tottenham 1954; Willemse 2001). Pelaksanaan penelitian dan pengambilan data dilaksanakan pada musim tanam kemarau II (MKII) bulan Juni sampai September 2014.

\section{Persiapan lahan percobaan dan penanaman}

Ukuran satu petak percobaan adalah 7,5 m x 20 m $(150 \mathrm{~m} 2)$ dan setiap perlakuan diulang sebanyak lima kali. Masing-masing petak perlakuan dipisahkan oleh area border dengan lebar $2 \mathrm{~m}$ yang dilengkapi saluran air dan penempatan petak perlakuan dilakukan secara acak sistematis (pengacakan dilakukan per kolom petak perlakuan). Penanaman dilakukan dengan jarak tanam $15 \mathrm{~cm}$ x $20 \mathrm{~cm}$. Benih kedelai yang digunakan adalah Anjasmoro. Aplikasi insektisida sintetik dilakukan pada pagi hari, sedangkan aplikasi insektisida nabati dan biologis dilakukan pada sore hari untuk mengurangi paparan sinar matahari. 


\section{Teknik Pengelolaan Hama}

Terdapat tiga teknik pengelolaan hama kedelai yang digunakan dalam penelitian ini, yaitu (1) teknik pengelolaan hama campuran (menggunakan insektisida nabati, biologi, dan sintetik), (2) teknik pengelolaan hama kedelai secara kimiawi (berbasis insektisida sintetik), dan (3) teknik pengelolaan hama kedelai versi petani (Tabel 1). Setiap proses aplikasi insektisida, masing-masing petak dikelilingi oleh border plastik dengan tinggi $1 \mathrm{~m}$, hal ini untuk mengurangi dampak penyemprotan terhadap petak lainnya. Di samping petak perlakuan, terdapat lahan kedelai yang dikelola oleh petani dan dijadikan sebagai acuan untuk jadwal aplikasi pada perlakuan teknik pengelolaan hama versi petani.

\section{Pengamatan langsung pada tanaman kedelai dan pemeliharaan parasitoid}

Pengamatan langsung pada tanaman kedelai dilakukan pada 10 satuan amatan untuk masing-masing perlakuan. Satu satuan amatan terdiri atas 4 rumpun tanaman kedelai yang dipilih secara acak membentuk huruf $X$ pada masing-masing petak percobaan. Rumpun amatan yang terpilih kemudian diamati dengan interval 1 minggu hingga menjelang panen. Pada pengamatan populasi kutukebul, pengamatan dilakukan pada satu daun trifoliet untuk masing-masing rumpun tanaman kedelai. Pengamatan juga dilakukan pada tanaman pinggir dan gulma yang dominan tumbuh di sekitar tanaman kedelai. Pemeliharaan serangga parasitoid dilakukan dengan mengumpulkan serangga hama yang terserang parasitoid di lahan kedelai dan memeliharanya di dalam cawan petri hingga imago parasitoid muncul. Serangga yang terserang parasitoid memiliki ciri bentuk tubuh abnormal, kurang aktif dan biasanya memiliki warna tubuh yang lebih gelap dibandingkan dengan serangga sehat.

Tabel 1. Komponen teknik pengelolaan hama yang digunakan.

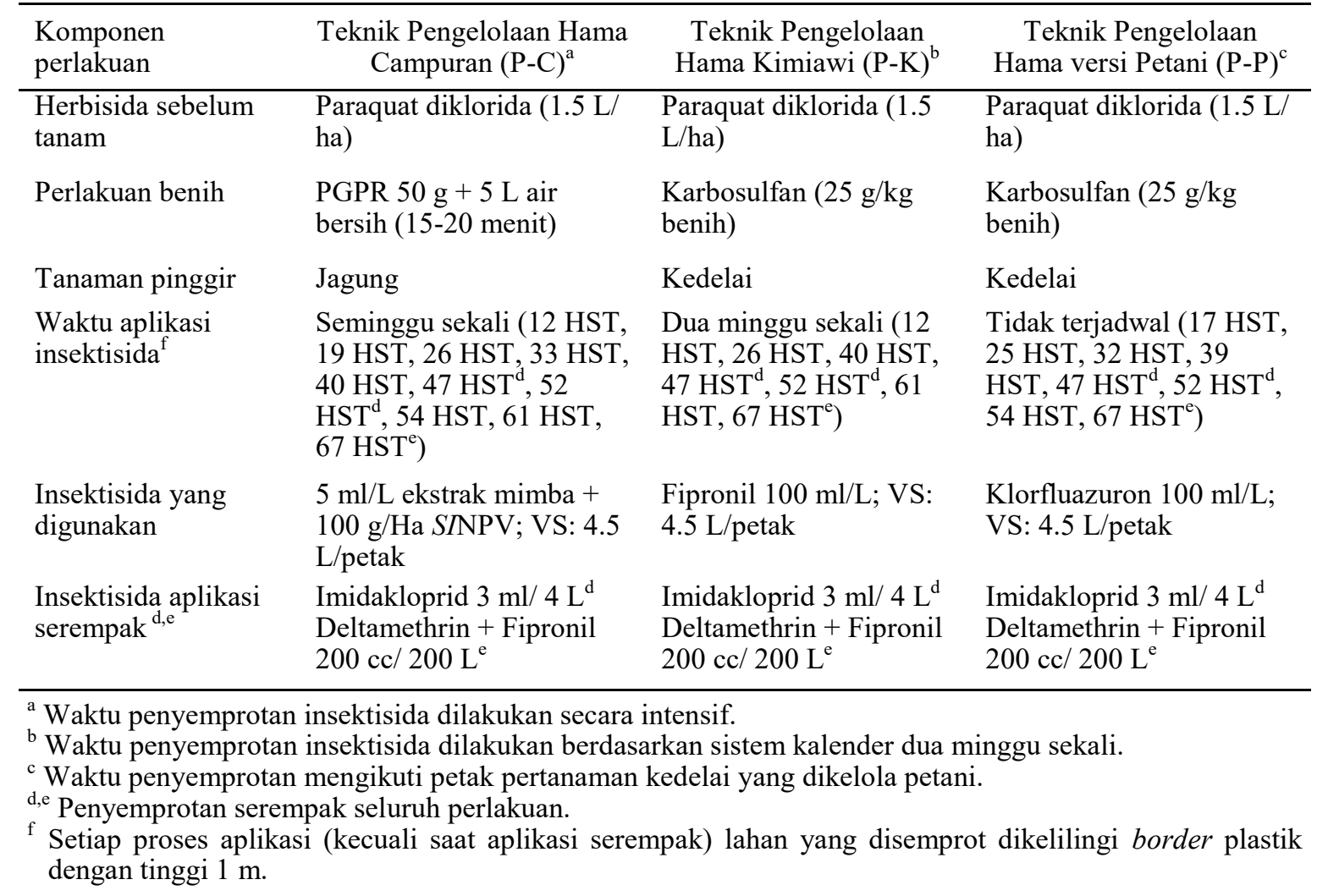




\section{Pengamatan dengan lubang jebakan dan jaring serangga}

Sebanyak lima buah lubang jebakan dipasang dengan pola huruf $\mathrm{X}$ pada masingmasing petak perlakuan. Satu lubang jebakan ditempatkan di tengah petak pengamatan dan empat lubang ditempatkan di masing-masing sisi dengan jarak $2 \mathrm{~m}$ dari tepi. Durasi pemasangan lubang perangkap adalah 24 jam. Penjaringan dilakukan dengan metode ayunan ganda pada lima titik yang sama dengan pemasangan lubang perangkap. Interval pengamatan adalah 1 minggu untuk pemasangan lubang jebakan dan penjaringan. Serangga yang terkoleksi kemudian dipilah dan dimasukkan ke dalam alkohol 70\% untuk proses identifikasi.

\section{Penyusunan pola interaksi bi-trofik dan analisis data}

Penyusunan hubungan bi-trofik serangga dilakukan berdasarkan hasil pengamatan langsung pada tanaman kedelai dan hasil pemeliharaan serangga. Komposisi serangga dianalisis berdasarkan data serangga yang terkoleksi dari lubang perangkap dan jaring serangga. Analisis dan pengolahan data menggunakan perangkat lunak $R$. Statistic 3.2.2 for Windows (Dormann et al. 2008; Oksanen et al. 2013; R-Core-Team 2015). Diagram Venn dibuat secara online pada website interaktif (Oliveros 2015). Data yang didapatkan dianalisis dengan menggunakan ANOVA yang dilanjutkan dengan uji Tukey pada tingkat kepercayaan 95\%.

\section{HASIL DAN PEMBAHASAN}

\section{Pola interaksi bi-trofik serangga hama dan} musuh alami

Hasil penyusunan pola interaksi bi-trofik menunjukkan bahwa teknik pengelolaan hama kimiawi berbasis insektisida sintetik memiliki pola yang sedikit lebih renggang dibandingkan dengan dua teknik pengelolaan hama lainnya (Gambar 1). Hal ini diduga disebabkan oleh
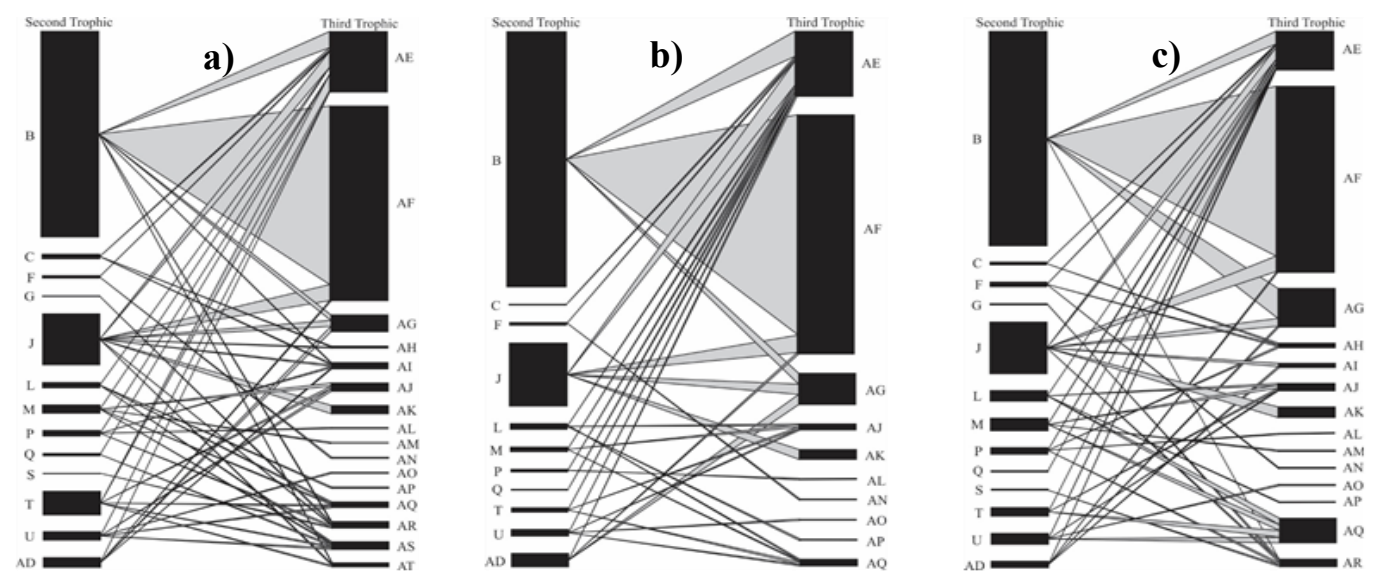

Gambar 1. Pola jejaring makanan pertanaman kedelai tingkatan trofik kedua dan ketiga. (a) teknik pengelolaan hama campuran (P-C); (b) teknik pengelolaan hama kimiawi ( $\mathrm{P}-$ $\mathrm{K})$; (c) teknik pengelolaan hama versi petani (P-P). Keterangan: $\mathrm{B}=$ Bemisia tabaci, $\mathrm{C}=$ Empoasca sp., $\mathrm{F}=$ Lamprosema indicata, $\mathrm{G}=$ Thrips sp., $\mathrm{J}=$ Aphis glycines, $\mathrm{L}=$ Spodoptera litura, $\mathrm{M}=$ Chrysodeixis, $\mathrm{P}=$ Caloptilia sp., $\mathrm{Q}=$ Nezara viridula, $\mathrm{S}=$ Tetranychus $\quad \mathrm{sp} ., \quad \mathrm{T}=$ Helicoperva armigera, $\mathrm{U}=$ Etiella zinckenella, $\mathrm{AD}=$ Pseudococcus $\quad$ sp., $\quad \mathrm{AE}=$ Lycosa $\quad$ sp., $\quad \mathrm{AF}=$ Menochilus sexmaculatus, $\mathrm{AG}=$ Verania $\quad$ sp., $\mathrm{AH}=$ Euborellia sp., $\mathrm{AI}=$ Chrysopa sp., $\mathrm{AJ}=$ Andrallus sp., $\mathrm{AK}=$ Syrphus sp., $\mathrm{AL}=$ Sympiesis sp., $\mathrm{AM}=$ Capidosoma sp., $\mathrm{AN}=$ Elasmus sp., $\mathrm{AO}=$ Baeognatha javana, $\mathrm{AP}=$ Brachymeria $\mathrm{sp} ., \mathrm{AQ}=$ Pheidole sp., $\mathrm{AR}=$ Geocoris sp., $\mathrm{AS}=$ Mantis sp., $\mathrm{AT}=$ Paederus fucipes . 
aplikasi insektisida yang cukup intensif. Zacharia (2011) melaporkan bahwa penggunaan pestisida dapat membunuh spesies kunci seperti musuh alami dan meningkatkan populasi dari spesies yang tidak diinginkan. Pestisida juga dapat menurunkan keanekaragaman dan kelimpahan spesies dalam ekosistem. Namun demikian, berdasarkan hasil analisis komposisi serangga pada masing-masing perlakuan menunjukkan hasil yang tidak berbeda nyata. Hasil ini berbeda dengan hasil yang dilaporkan oleh Dawoud et al. (2017), yang melaporkan aplikasi pestisida memengaruhi jejaring makanan pada ekosistem aliran detrital.

Jumlah spesies artropoda entomofag yang ditemukan pada petak teknik pengelolaan hama kimiawi lebih sedikit dibandingkan dengan jumlah spesies pada teknik pengelolaan hama campuran dan teknik pengelolaan hama versi petani. Pola interaksi bi-trofik yang disusun berdasarkan kelimpahan populasi dari masing-masing struktur trofik menunjukkan dominansi dari masing-masing struktur trofik pada kedua tingkatan trofik (Schigel 2011). Lebar pita untuk tingkatan trofik ketiga pada diagram pola interaksi bi-trofik mewakili populasi dari masingmasing struktur trofik yang ada pada tingkatan trofik tersebut. Sedangkan lebar pita pada tingkatan trofik kedua mewakili jumlah predator atau parasitoid yang memangsa masing-masing struktur trofik pada tingkatan trofik kedua.

Kutukebul Bemisia tabaci merupakan serangga fitofag yang paling dominan ditemukan di ketiga lahan perlakuan. Kondisi ini menunjukkan bahwa kutukebul merupakan struktur trofik yang penting pada ekosistem pertanaman kedelai. Kutukebul merupakan salah satu hama penting pada tanaman kedelai. Hal ini disebabkan selain berperan sebagai hama yang menyebabkan kerusakan langsung pada tanaman kedelai, kutukebul juga berperan sebagai vektor virus CMMV (cowpea mild mottle virus) yang menyerang tanaman kedelai. Kondisi lingkungan saat penelitian sangat mendukung perkembangan populasi kutukebul. Subagyo \& Hidayat (2014) melaporkan bahwa semakin tinggi suhu lingkungan, maka akan meningkatkan laju reproduksi kutukebul. Secara langsung, perubahan kondisi lingkungan dapat memengaruhi kelimpahan populasi serangga dan secara tidak langsung memengaruhi panjang dan kompleksitas jejaring makanan yang ada (Harmon et al. 2009; Tunney et al. 2012).

Serangga fitofag lain yang populasinya cukup tinggi adalah kutudaun (Aphis glycines) dan ulat Helicoperva armigera. Sedangkan entomofag yang paling dominan ditemukan di ketiga petak perlakuan adalah kumbang koksi (Menochilus sexmaculatus). Tingginya populasi kumbang koksi ini berhubungan dengan tingginya populasi kutudaun. Kutudaun merupakan salah satu mangsa kumbang koksi. Saleem et al. (2014) melaporkan bahwa kumbang M. sexmaculatus merupakan predator yang memangsa serangga kecil bertubuh lunak seperti kutudaun, kutukebul, dan trips. Entomofag lain yang dominan ditemukan di ketiga perlakuan adalah laba-laba Lycos sp., laba-laba ini merupakan salah satu struktur trofik penting pada berbagai ekosistem pertanian termasuk ekosistem pertanaman kedelai.

Menurut penelitian Arifin (2012) penggunaan insektisida $S I N P V$ pada tanaman kedelai dapat menurunkan populasi ulat 
grayak sebesar $88 \%$ dan menyelamatkan kehilangan hasil $14 \%$ lebih tinggi dibanding aplikasi insektisida kimia yang dianjurkan. Namun, hasil penelitian menunjukkan bahwa aplikasi SlNPV yang dikombinasikan dengan ekstrak mimba, PGPR, dan tanaman pinggir jagung tidak memberikan pengaruh yang nyata terhadap komposisi dan kelimpahan serangga pada lahan pertanaman kedelai. Kondisi ini diduga disebabkan oleh aplikasi SlNPV dan insektisida nabati lainnya yang terlalu intensif, sehingga memengaruhi komposisi serangga dan mengurangi keanekaragaman serangga di pertanaman kedelai. Faktor lain yang dapat memengaruhi kondisi ini adalah tingginya populasi kutukebul yang memengaruhi stabilitas jejaring makanan di pertanaman kedelai.

\section{Keanekaragaman dan kelimpahan serangga di pertanaman kedelai}

Keanekaragaman dan kelimpahan spesies serangga diamati dengan menggunakan perangkap lubang dan jaring serangga. Hasil analisis menunjukkan bahwa keanekaragaman dan kelimpahan serangga pada masing-masing teknik pengelolaan hama tidak berbeda nyata (Tabel 2). Hasil ini sejalan dengan hasil penelitian Afifah dkk. (2015) yang melaporkan bahwa bahwa pengelolaan kesehatan tanaman berbasis pengelolaan hama terpadu (PHT), pengendalian hama non-kimiawi, dan pengendalian hama kimiawi pada tanaman kedelai tidak memengaruhi keanekaragaman serangga didalamnya. Kelimpahan populasi serangga hama, parasitoid, predator, dan saprofag tidak berbeda nyata pada ketiga teknik pengelolaan hama. Hasil ini sedikit berbeda dengan hasil penelitian Afifah dkk. (2015) yang menyebutkan bahwa perbedaan pengelolaan kesehatan tanaman tidak memengaruhi kelimpahan populasi hama namun memengaruhi kelimpahan populasi serangga saprofag, parasitoid, dan predator.

Jumlah spesies artropoda yang ditemukan dari penelitian ini berjumlah 188 spesies yang berasal dari 83 famili dan 13 ordo. Adapun hasil penelitian lain oleh Afifah dkk. (2015) menemukan 539 morfospesies dari 122 famili dan 14 ordo pada pertanaman kedelai Anjasmoro dan Wilis. Perbedaan ini disebabkan oleh jenis perangkap yang

Tabel 2. Keanekaragaman dan kelimpahan serangga pada masing-masing teknik pengelolaan hama.

\begin{tabular}{|c|c|c|c|}
\hline \multirow{2}{*}{ Peranan Ekologi } & \multicolumn{3}{|c|}{ Teknik Pengelolaan Hama } \\
\hline & $\mathrm{P}-\mathrm{C}^{1}$ & $\mathrm{P}-\mathrm{K}^{2}$ & P-P ${ }^{3}$ \\
\hline & \multicolumn{3}{|c|}{ Keanekaragaman Spesies Serangga $($ Mean \pm SD) } \\
\hline Fitofag & $32.0 \pm 2.45$ & $28.6 \pm 2.30$ & $30.2 \pm 4.49$ \\
\hline Parasitoid & $12.8 \pm 4.15$ & $14.6 \pm 3.58$ & $14.6 \pm 1.82$ \\
\hline Predator & $17.4 \pm 2.41$ & $18.6 \pm 2.70$ & $17.0 \pm 1.00$ \\
\hline \multirow[t]{2}{*}{ Saprofag } & $8.6 \pm 1.34$ & $10.4 \pm 1.52$ & $10.4 \pm 0.55$ \\
\hline & \multicolumn{3}{|c|}{ Kelimpahan Individu Serangga (Mean \pm SD $)$} \\
\hline Fitofag & $6589.2 \pm 2847.03$ & $6859.0 \pm 3663.96$ & $5173.4 \pm 2224.23$ \\
\hline Parasitoid & $23.8 \pm 5.50$ & $25.8 \pm 7.12$ & $30.4 \pm 2.88$ \\
\hline Predator & $92.4 \pm 6.91$ & $105.0 \pm 18.21$ & $99.8 \pm 12.83$ \\
\hline Saprofag & $1375.4 \pm 230.44$ & $1351.4 \pm 281.88$ & $1353.8 \pm 232.62$ \\
\hline
\end{tabular}


digunakan dan tingkat identifikasi yang dilakukan. Afifah dkk. (2015) menggunakan 4 jenis perangkap (lubang jebakan, nampan kuning, perangkap berperekat dan jaring serangga), sedangkan pada penelitian ini hanya digunakan 2 perangkap (lubang jebakan dan jaring serangga) untuk mendapatkan data kelimpahan dan keanekaragaman serangga. Penggunaan lebih banyak jenis perangkap dapat meningkatkan jumlah serangga yang diperoleh. Akan tetapi, identifikasi pada penelitian Afifah dkk. (2015) dilakukan hingga tingkat morfospesies, sedangkan pada penelitian ini identifikasi dilakukan hingga tingkat spesies.

Semua spesies yang teridentifikasi pada penelitian ini juga ditemukan pada hasil penelitian Afifah dkk. (2015). Akan tetapi, terjadi adanya pergeseran serangga dominan yang ditemukan di pertanaman kedelai. Penelitian Afifah dkk. (2015) melaporkan spesies serangga fitofag dengan kelimpahan tertinggi adalah Empoasca sp., sedangkan pada penelitian ini adalah B. tabaci. Begitu pula dengan serangga entomofag dengan kelimpahan tertinggi pada penelitian ini adalah Forcipomyia sp., sedangkan pada penelitian Afifah dkk. (2015) adalah famili Conopidae.
Perubahan struktur pada salah satu tingkatan trofik akan memengaruhi panjang dan komposisi jejaring makanan yang terbentuk (Eveleigh et al. 2007; Yang \& Gratton 2014). Kehilangan spesies atau dominansi salah satu spesies dalam tingkatan trofik akan memengaruhi jejaring makanan dan keseluruhan ekosistem (Cagnolo et al. 2009).

\section{Komposisi dan kekayaan spesies serangga di pertanaman kedelai}

Berdasarkan hasil analisis indeks kemiripan komposisi serangga (ANOSIM) terhadap hasil pengamatan langsung pada tanaman kedelai menunjukkan hasil yang tidak berbeda nyata (nilai $\mathrm{R}=0 ; \mathrm{P}=1.67$ ). Hasil penyusunan dendogram menunjukkan bahwa komposisi serangga pada teknik pengelolaan hama campuran lebih mirip dengan komposisi serangga pada teknik pengelolaan hama kimiawi berbasis insektisida sintetik. Teknik pengelolaan hama versi petani memiliki komposisi serangga yang berbeda dibandingkan dengan dua perlakuan lainnya (Gambar 2). Menurut Hughes et al. (2000) keanekaragaman spesies serangga akan berbeda untuk setiap habitat. Selain itu, faktor lain yang dapat menyebabkan perbedaan

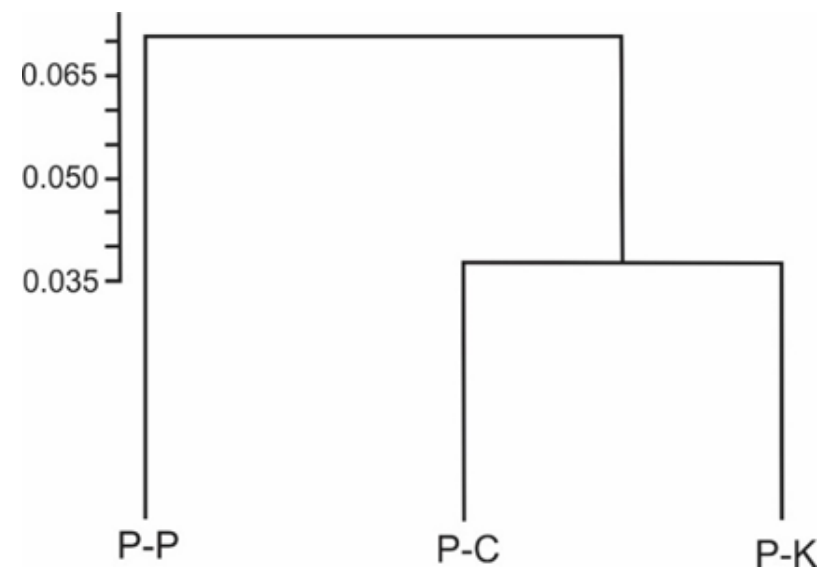

Gambar 2. Dendrogram kemiripan komposisi spesies serangga pada masing-masing teknik pengelolaan hama. P-C: teknik pengelolaan hama campuran; P-K: teknik pengelolaan hama kimiawi; P-P: teknik pengelolaan hama versi petani. 


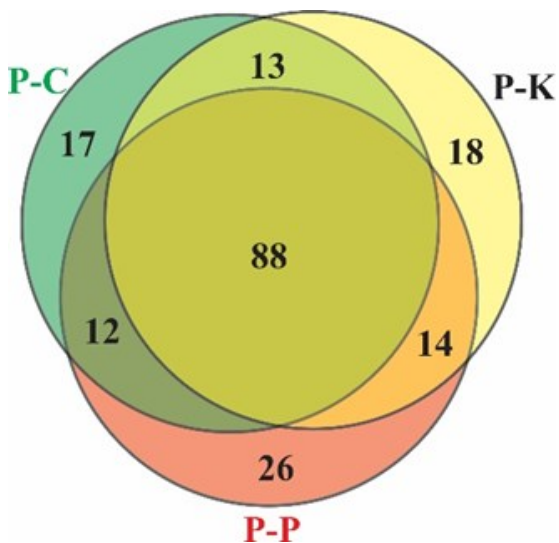

Gambar 3. Diagram Venn yang menunjukkan himpunan spesies dari masingmasing petak pengelolaan hama. P-C: teknik pengelolaan hama campuran; P-K: teknik pengelolaan hama kimiawi; PP: teknik pengelolaan hama versi petani.

komposisi spesies serangga adalah adanya perbedaan karakteristik lingkungan disekitar habitat utama (Humphrey et al. 1999; Korpela et al. 2015). Pada habitat yang sama, perbedaan komposisi serangga jarang terjadi, kecuali adanya intervensi dari manusia (Son et al. 2016).

Penggambaran kekayaan spesies serangga pada ketiga teknik pengelolaan hama menunjukkan adanya spesies yang tumpang tindih (Gambar 3). Sebanyak 88 spesies yang sama ditemukan di ketiga teknik pengelolaan hama. Sebanyak 17 spesies hanya ditemukan di petak perlakuan P-C, 18 spesies hanya ditemukan di petak perlakuan P-K dan sebanyak 26 spesies hanya ditemukan di petak perlakuan P-P. Kekayaan jumlah spesies di lahan pertanaman kedelai ini diduga berhubungan dengan intensitas penyemprotan insektisida yang dilakukan. Zacharia (2011) melaporkan bahwa intensitas aplikasi insektisida sangat memengaruhi baik keanekaragaman maupun kelimpahan spesies serangga. Kegiatan pengendalian hama menggunakan insektisida nabati dan biologis tetap akan memengaruhi kekayaan spesies serangga yang ada jika dilakukan dengan intensitas yang tinggi. Hal ini yang menyebabkan kekayaan spesies serangga pada teknik pengelolaan hama campuran dan kimiawi memiliki kekayaan spesies serangga yang lebih rendah dibandingkan teknik pengelolaan hama versi petani.

\section{KESIMPULAN}

Pola interaksi bi-trofik pada teknik pengelolaan hama kimiawi berbasis insektisida sintetik sedikit lebih renggang dibandingkan dengan dua teknik pengelolaan hama lainnya. Namun komposisi spesies serangga pada masing-masing teknik pengelolaan hama tidak memiliki perbedaan yang nyata. Spesies serangga pada teknik pengelolaan hama campuran lebih mirip dengan spesies serangga pada teknik pengelolaan hama kimiawi dibandingkan dengan teknik pengelolaan hama versi petani. Intensitas aplikasi insektisida memengaruhi kekayaan spesies serangga. Teknik pengelolaan hama versi petani memiliki tingkat kekayaan spesies serangga yang lebih tinggi dikarenakan memiliki intensitas aplikasi insektisida yang lebih rendah dibandingkan dengan dua teknik pengelolaan hama lainnya.

\section{DAFTAR PUSTAKA}

Afifah, L., Hidayat, P., Buchori, D. \& Rahardjo, B. T. (2015). Pengaruh perbedaan pengelolaan agroekosistem tanaman terhadap struktur komunitas serangga pada pertanaman kedelai di Ngale, Kabupaten Ngawi, Jawa Timur. Jurnal Hama Dan Penyakit Tumbuhan Tropika, 15(1), 53-64. https://doi.org/https:// doi.org/10.23960/j.hptt.11553-64.

Allesina, S., Grilli, J., Barabás, G., Tang, S., Aljadeff, 
J. \& Maritan, A. (2015). Predicting the stability of large structured food webs. Nature Commun., 6(1), 1-6. https://doi.org/10.1038/ ncomms 8842 .

Arifin, M. (2012). Bioinsektisida SINPV untuk mengendalikan ulat grayak mendukung swasembada kedelai. J Peng Inov Pert, 5(1), 22.

Begon, M., Townsend, C. \& Harper, J. (2003). Ecology - from individuals to ecosystems. Blackwell Publisher.

Cagnolo, L., Valladares, G., Salvo, A., Cabido, M. \& Zak, M. (2009). Habitat fragmentation and species loss across three interacting trophic levels: effects of life-history and food-web traits. Conservation Biology, 23(5), 1167-1175. https://doi.org/10.1111/j.1523 $-1739.2009 .01214 . x$.

Choate, P. M. (1990). Checklist of the ground beetles of Florida (Coleoptera: Carabidae) literature records. Florida Entomologist, 476-492.

Dawoud, M., Bundschuh, M., Goedkoop, W. \& McKie, B. G. (2017). Interactive effects of an insecticide and a fungicide on different organism groups and ecosystem functioning in a stream detrital food web. Aquatic Toxicology, 186, 215-221. https://doi.org/ 10.1016/j.aquatox.2017.03.008.

Disney, R. H. L. \& Fayle, T. M. (2008). A new species of scuttle fly (Diptera: Phoridae) parasitizing an ant (Hymenoptera: Formicidae) in Bomeo. Sociobiology, 51(2), 327332.

Dondale, C. D. \& Redner, J. H. (1990). The insects and arachnids of Canada. Part 17. The wolf spiders, nurseryweb spiders, and lynx spiders of Canada and Alaska. Araneae: Lycosidae, Pisauridae, and Oxyopidae. Canada Agr (English Ed.), 1856.

Dormann, C. F., Gruber, B. \& Fruend, J. (2008).
Introducing the bipartite Package: Analysing Ecological Networks. R News, 8(2), 8-11.

Eveleigh, E. S., McCann, K. S., McCarthy, P. C., Pollock, S. J., Lucarotti, C. J., Morin, B., McDougall, G. A., Strongman, D. B., Huber, J. T., Umbanhowar, J. \& Faria, L. D. B. (2007). Fluctuations in density of an outbreak species drive diversity cascades in food webs. Proceedings of the National Academy of Sciences of the United States of America, 104 (43), 16976-16981. https://doi.org/10.1073/ pnas.0704301104.

Froeschner, R. C. (1996). Lace bug genera of the world. Smithsonian Institution Press.

Goulet, H. \& Huber, J. T. (1993). Hymenoptera of the world: an identifixation guide to families. Canada Communication Group.

Gurr, G. M., Wratten, S. D., Landis, D. A. \& You, M. (2017). Habitat management to suppress pest populations: progress and prospects. Annu. Rev. Entomol., 62(1), 91-109. https:// doi.org/10.1146/annurev-ento-031616035050 .

Harmon, J. P., Moran, N. A. \& Ives, A. R. (2009). Species response to environmental change: impacts of food web interactions and evolution. Science, 323(5919), 1347-1350. https://doi.org/10.1126/science.1167396.

Hassan, K., Pervin, M., Mondal, F. \& Mala, M. (2016). Habitat management: a key option to enhance natural enemies of crop pest. Univ. J. Plan. Sci., 4(4), 50-57. https:// doi.org/10.13189/ujps.2016.040402.

Heraty, J. (2017). Parasitoid Biodiversity and Insect Pest Management. In R. Foottit \& P. Adler (Eds.), Insect Biodiversity: Science and Society (Vol. 2, pp. 603-625). John Wiley \& Sons, Ltd. https://doi.org/10.1002/ 9781118945568.ch19.

Hughes, J. B., Daily, G. C. \& Ehrlich, P. R. (2000). 
Conservation of insect diversity: a habitat approach. Conservation Biology, 14(6), 1788-1797. https://doi.org/10.1111/j.15231739.2000.99187.x.

Humphrey, J. W., Hawes, C., Peace, A. J., Ferris-Kaan, R. \& Jukes, M. R. (1999). Relationships between insect diversity and habitat characteristics in plantation forests. For. Ecol. Manage., 113(1), 11-21. https:// doi.org/10.1016/S0378-1127(98)00413-7.

Jocqué, R., \& Alderweireldt, M. (2005). Lycosidae: the grassland spiders. Acta Zool Bulg, 1(1), $125-130$.

Korpela, E.-L., Hyvönen, T. \& Kuussaari, M. (2015). Logging in boreal field-forest ecotones promotes flower-visiting insect diversity and modifies insect community composition. Insect Conserv. Divers, 8(2), 152-162. https://doi.org/10.1111/icad.12094.

Loch, J. M. H., Walters, L. J. \& Cook, G. S. (2020). Recovering trophic structure through habitat restoration: A review. Food Webs, 25, e00162. https://doi.org/10.1016/j.fooweb. 2020.e00162

Macfadyen, S., Davies, A. P., \& Zalucki, M. P. (2015). Assessing the impact of arthropod natural enemies on crop pests at the field scale. Insect Sci., 22(1), 20-34. https:// doi.org/10.1111/1744-7917.12174.

Malard, J. J., Adamowski, J. F., Rojas Díaz, M., Nassar, J. B., Anandaraja, N., Tuy, H., Arévalo-Rodriguez, L. A. \& MelgarQuiñonez, H. R. (2020). Agroecological food web modelling to evaluate and design organic and conventional agricultural systems. Eco.l Modell., 421, 108961. https:// doi.org/10.1016/j.ecolmodel.2020.108961.

Masner, L. (1980). Key to genera of Scelionidae of the Holarctic region, with descriptions of new genera and species (Hymenoptera:
Proctotrupoidea). Mem Entomol Soc Canada, 112(S113), 1-54.

McAlpine, J. F. (1987). Lonchaeidae. In J. F. McAlpine (Ed.), Manual of Nearctic Diptera volume 2 (pp. 791-798). Canada Communication Grup.

McCary, M. A., Mores, R., Farfan, M. A. \& Wise, D. H. (2016). Invasive plants have different effects on trophic structure of green and brown food webs in terrestrial ecosystems: a meta-analysis. Ecol. Lett., 19(3), 328-335. https://doi.org/10.1111/ele.12562.

McMeans, B. C., McCann, K. S., Humphries, M., Rooney, N. \& Fisk, A. T. (2015). Food web structure in temporally-forced ecosystems. In Trends Ecol. Evol., 30(11,) pp. 662-672). Elsevier Ltd. https://doi.org/10.1016/ j.tree.2015.09.001.

Mougi, A. \& Kondoh, M. (2016). Food-web complexity, meta-community complexity and community stability. Sci. Rep., 6(1), 1-5. https://doi.org/10.1038/srep24478.

Oksanen, J., Blanchet, F. G., Kindt, R., Legendre, P., Minchin, P. R., O’Hara, R. B., Simpson, G. L., Solymos, P., Stevens, M. H. H. \& Wagner, H. (2013). vegan: Community Ecology Package. R package version 2.0-10. [Online]. Diambil dari http://CRAN.R-project.org/ package=vegan .

Oliveros, J. C. (2015). Venny. An interactive tool for comparing lists with Venn's diagrams. [Online]. Diambil dari http:// bioinfogp.cnb.csic.es/tools/venny/index.html.

Rao, B. R. S. \& Hayat, M. (1983). Key to the genera of Oriental Mymaridae, with a preliminary catalog (Hymenoptera: Chalcidoidea). Contrib of the Ame Entomol Inst.

R-Core-Team. (2015). R: A language and environment for statistical computing. $\mathrm{R}$ Foundation for Statistical Computing. 
[Online]. Diambil https://www.Rproject.org/.

Saleem, M., Hussain, D., Anwar, H., Ghouse, G. \& Abbas, M. (2014). Predation Efficacy of Menochilus sexmaculatus Fabricus (Coleoptera: Coccinellidae) against Macrosiphum rosae under laboratory conditions. J Entomol Zool Studi, 2(3), 160163.

Schigel, D. S. (2011). Fungus-beetle food web patterns in boreal forests. Russian Entomol. J., 20(2), 141-150.

Slater, J. A. \& Baranowski, R. M. (1990). Lygaeidae of Florida (Hemiptera: Heteroptera) (Vol. 14). Florida Departement of Agriculture and Consumer Services.

Smith, R. \& Holmes, A. (2002). Literature-based key to Florida "burrowing bugs" (Heteroptera: Cydnidae). Pub ENY, 4161(6166), 15.

Son, J.-K., Kong, M.-J., Kang, D.-H., Kang, B., Yun, S.-W. \& Lee, S.-Y. (2016). The comparative studies on the terrestrial insect diversity in protected horticulture complex and paddy wetland. Journal of Wetlands Research, 18 (4), 386-393. https://doi.org/10.17663/ jwr.2016.18.4.386.

Subagyo, V. N. O. \& Hidayat, P. (2014). Neraca kehidupan kutukebul Bemisia tabaci (Gennadius) (Hemiptera: Aleyrodidae) pada tanaman cabai dan gulma babadotan pada suhu $25^{\circ} \mathrm{C}$ dan $29^{\circ} \mathrm{C}$. J Entomol Indon, 11 (1), 11-18.

Tottenham, C. E. (1954). Handbooks for the identification of British insects vol. IV part 8a. In C. E. Tottenham (Ed.), Coleoptera, Staphylinidae, Section (a): Piestinae to Euaesthhetinae. Royal Entomological Society of London.

Tunney, T. D., McCann, K. S., Lester, N. P. \& Shuter, B. J. (2012). Food web expansion and contraction in response to changing environmental conditions. Nature Comm., 3(1), 1-9. https://doi.org/10.1038/ncomms2098.

Willemse, L. P. M. (2001). Fauna Malesiana guide to the pest Orthoptera of the Indo-Malayan region. Backhuys Publishers.

Yang, L. H. \& Gratton, C. (2014). Insects as drivers of ecosystem processes. In Current Opinion in Insect Science (Vol. 2, pp. 26-32). Elsevier Inc. https://doi.org/10.1016/j.cois.2014.06. 004.

Zacharia, J. T. (2011). Ecological effects of pesticides. In M. Stoytcgeva (Ed.), Pesticides in the Modern World-Risks and Benefits. InTech. 